Research in Social Sciences

ISSN: 2641-5305

Vol. 1, No. 2, pp. 37-43

2018

DOI: $10.53935 / 2641-5305 . v 1 i 2.6$

(C) 2018 by the authors; licensee Academic Publishing Group

\section{The Conducting of Instrumental and Choral Ensembles and the Nigerian Audience}

Sunday N. Nnamani: Dept of FAA/ Music, Federal University Ndufu-Alike IKWO, PMB 1010 Abakaliki Ebonyi State Nigeria.

ABSTRACT: The conducting profession had through the years been an exclusive right of a gifted and sensitive musician, capable of dealing authoritatively with professionals in their own field while possessing the right attitude to understand the need of his audience. This paper titled "The conducting of instrumental and choral ensembles and the Nigerian Audience" examines the historical development of conducting from early times through to the 20th Century. It further sees the conductor as more than a mere time beater but as one who is always faced with an increasing complexity of musical scores especially of the orchestral in addition to a high standard of performance always demanded by a critical audience. He must possess the ability to detect, diagnose and remedy a musical fault almost in a flash. Finally, the paper x-rays the contributions of the Muson Centre Lagos, some churches and private choral groups in Nigeria.

Key words: Ability to detect, Diagnose, Indicate Speed, Dynamics, Careful preparation.

\section{Introduction}

Conducting may be defined as the communication by means of gestures of an interpretation of a musical work to a group of musicians performing it. The group usually involves a chorus, an orchestra, a band or mixed vocal and instrumental ensemble.

The Lexicon Webster Dictionary, Pei (1983) described a conductor as;

One who conducts, a leader, a guide, a director or manager, the director of an orchestra or chorus who indicates to the performers by rhythm and expression of the music as by motions of a baton. (p. 211)

In the same vein Norton (1994) defines a conductor in music as "a person who conducts an orchestra, chorus, opera company, ballet or other musical group in the performance and interpretation of ensemble works" (p. 524)

Nnamani (2009) defined it as the communication by means of gesture of an interpretation of a musical work to a group of musicians performing it. The group may be an orchestra, band, chorus or mixed vocal instrumental ensemble (p. 6)

To be precise, conducting involves not only correct indication of speed, dynamics and phrasing but also careful preparation to ensure that the balance is correct and that the intents of a composer are adequately represented. Unlike a singer or an instrumentalist, the conductor has to persuade others to accept his views of the music and so help him to shape it into a unified and convincing whole. A conductor is primarily a teacher and teaching is his primary function especially during rehearsals. The method by which this is achieved varies according to the individual concerned. Some conductors make detailed markings on the orchestral or vocal scores indicating details of bowing to the string players or breathing to the singers. Others rely on verbal 
instructions at rehearsals and on the impression of a strong personality. Thus, a conductor, is only as good as the result he obtains from the work of others.

\section{Essentials of Conducting}

The essentials of conducting that will probably lead to a successful performance include;

a) the conductor's inner vision

b) his ability to detect errors, make diagnosis and

c) his ability to proffer solutions to identified problems.

An experienced conductor is one in whom this three-fold action of detection, diagnosis and remedy takes place almost in a twinkle of an eye. A careful combination and application of the above principles will yield good dividend in the conducting process.

\subsection{The History of the Development of Conducting}

Conducting became a specialized form of musical activity in the early $19^{\text {th }}$ century.

According to Norton (1994), he said, "as early as the $15^{\text {th }}$ century, performances by the Sistine Choir in the Vatican were kept together by slapping a roll of paper or a lengthy pole to maintain audible beat". (p. 524). This practice continued until it was clear that it was an intrusion into the performance and it was then abandoned. In the Baroque era, harmonies provided by the keyboard players (organ or harpsichord) were an essential feature of most music and the conductor often kept the ensemble together by a steady background beat on the instrument. Later in the mid $17^{\text {th }}$ and $18^{\text {th }}$ centuries at the Paris Opera, the portion of the conductor fell to the concert master operating from the first violin desk. He was also meant to handle the complicated scores as best as he could. Throughout this period the conductor was largely a major functionary, first among equals whose chief responsibility was to perform with the ensemble and secondly to lead it to a successful outing. In the $19^{\text {th }}$ century, conducting gradually became a fulltime virtuoso profession. This was partly the result of the efforts by the composer conductor to achieve higher standards of performance and also an outgrowth of the new aesthetic ideals of the $19^{\text {th }}$ century Romanticism. These ideals elevated music to a higher position in the arts than it had held before. Prominent among them were composers such as Maris von Weber, Hector Berlioz, Felix Mendelssohon and Richard Wagner. These were men of autocratic and creative character, who assumed full control of their works and their performances. The result was that it brought to their works, a single-minded creative viewpoint and a cultivated sensitivity in the assessment of such creative outputs. These later became the hallmark of most of the works of the $19^{\text {th }}$ century music. For example, some of these new breed composer-conductors wielded such influences that they were unable to champion successfully, some unpopular causes. A case in reference was Mendelssohn's revival of the music of J. S. Bach considered at that time to be old-fashioned because it was a mere academic exercise.

Concluding this discussion, Westrup et al (1976) asserted that through the works of Berlioz, Wagner and others ..."the $19^{\text {th }}$ century conductor, needed to be a consummate musician, with an intimate understanding of every detail of the score and the power to communicate his understanding to others". (p.276)

By the beginning of the $20^{\text {th }}$ century, the tradition of the composer-conductor was carried forth by musicians such as American Leonard Bernstein, French Pierre Boulez and Lukas Foss, a German bornAmerican. The increased importance of the composer-conductor later gave rise to musicians known primarily as just conductors, hence the use of the word "Star Conductor". The star conductor was worshipped and rated highly as the operatic singer of the $18^{\text {th }}$ and $19^{\text {th }}$ centuries.

The work of such conductors and conductor-composers generally forged the modern concept of orchestral and choral performance as a unified musical interpretation guided by a single mind. Confirming the above; Norton (1994) said,

the most effective $20^{\text {th }}$ century conductors have been both gifted musicians, skilled and sensitive leaders, capable of dealing authoritatively with professionals in their own field while possessing the deftness to understand the needs of their economic supporters and public. (p. 520)

The researcher rightly agrees with the above because a good conductor must first be self-confident and also show convincingly the "rightness" of his interpretation either by his show of erudition, artistry or even by mere force of his personality. 
In African music, due to the high sense of metronome sense inherent in the African performer, the master drummer performs the work of the conductor. He uses his drum to change the rhythmic pace and style of the music.

Some of the renowned $20^{\text {th }}$ century conductors include;

a) Han von Biilow, a German

b) Hans Ritcher (1843-1916), a Hungarian

c) Artuno Toscanini, an Italian and

d) Fritz Reiner, a Hungarian-American

Because the $20^{\text {th }}$ century conductor received such a public admiration and prestige reserved for the $19^{\text {th }}$ century Romantic pianists and in the $18^{\text {th }}$ century, for the vocal virtuoso, they had been in a position to promote various causes of the musical profession.

\subsection{The Modern Conductor}

To the modern conductor, conducting is to bring forth thrilling music from a group of singers or players to inspire them through one's personal magnetism. His other job is to excel in training them through his own musicianship to become musicians themselves to personally feel the power of music so deeply that the audience will be lifted to new heights emotionally. The art of conducting therefore is the height and most complete synthesis of all the facets of musical activity. The conductor is the one who constantly arrives in his mind, the musical sound. He is a MERCHANT In Sound, And Infact Sound Is His Stock In Trade. The art of conducting is not just stepping on the complex and demanding activities in the realm of music, but it comprises both the visual public performance and the constant applications of the conducting technique.

\subsection{The Public Concert Hall}

As music moved from the palace and the church to public concert hall, the size of the orchestra increased and it became efficient giving rise to a wide range of expressions, more varied and colorful than ever before, that the conductor can express on. This naturally had a direct influence on the sound that was produced. For example, where most $18^{\text {th }}$ century music ranged in dynamic level from piano to forte, the dynamic range of the orchestra in the $19^{\text {th }}$ century was far greater. This therefore brought in the heaven-storming crescendos, the violent contrasts of loud and soft that lend such drama to the music of the Romantics. As orchestral music became more and more important, the technique of writing for the orchestra became almost an art in itself.

Then at last the musician had a palette comparable to the painter's, and used it as the painter did - to conjure up sensuous beauty and enchantment to create mood and atmosphere, to suggest nature scenes and calm seascapes (Machlis, 1984).

\section{Trend of Development in Public Performance}

Ideally, a good performance represents the musical thought of the performer, as he re-thinks the music written by the composer. If the composer is dead we cannot know to what extent this corresponds to the composer's own thought of his music. It could happen though, that a great interpreter can perform the music even better than what the original composer had imagined. But the result depends largely on the expertise and competence of the conductor (interpreter). This situation is very rare in real musical situation. Some composers excel at performance details more than others. We consider "better" here as meaning not more accurate, or technically brilliant, but as revealing more meaning, a greater penetration of mysteries of the human psyche. The piece to be interpreted becomes a tool for revealing the richness of life, the beautiful - an entrance to a "better world" as the Schubert song "An die Musick" tells us. We are profoundly ignorant of what the word profound means, but we can feel it. In that sense interpreting a piece of music is a treasure hunt and each treasure found is a portal to an even greater treasure. The trend of development in public musical performances began in Italy where there were semi-private academies of the Renaissance and which later continued to flourish in the $17^{\text {th }}$ century. Galileo who belonged to the group called the Florentine Camerata first sowed the seed that later developed into an opera. At first, opera was a fairly exclusive affair of the nobility, most of whom throughout the entire Baroque period maintained their own players, singers and sometimes composers. From the later half of the $17^{\text {th }}$ century, many of the big churches provided from time to

Research in Social Sciences Vol. 1, No. 2, pp. 37-43 2018

DOI: 10.53935/2641-5305.v1i2.6

Email: sundaynnamani2010@yahoo.com Funding: This study received no specific financial support.

Received: 16 August 2018

Revised: 24 September 2018

Revised: 24 September 2018

Accepted: 29 October 2018

() 2018 by the authors; licensee Academic

() 2018 by the aut 1 .
Pushing Group

| 39 
time opportunities for concerts of vocal and instrumental music. The tradition spread from Italy to Germany and later to France and England.

Speaking specifically on these developments Robertson and Stevens (1981) said;

Public concerts proper were first founded in Germany by Buxtehude, who in 1673, organized a series of evening concerts, mostly of sacred works, in Lübeck on the five Sundays before Christmas; they were continued until the early $19^{\text {th }}$ century and their fame was the cause of Bach's celebrated 200-mile journey in 1705 . (p

In the same vein other concert series were started by Bach's contemporary Telemann in Frankfurt in Hamburg and Leipzig (1781) which eventually developed into the renowned Gewandhaus concerts.

\subsection{The Baroque Orchestra}

The Baroque was a period of international culture when national styles existed without nationalism. Towards the end of the $17^{\text {th }}$ century, a generally recognized distinction in style began to be made between chamber music and orchestral music. The orchestra available to Bach and Handel consisted of groups made up of violins, violas, cellos and double basses. The other group was made up of flutes, oboes and bassoons. Some other types of brass instruments were also in use. The most famous orchestral format of the Baroque era took the form of the concerto-grosso. The concerto-grosso principle was that of opposition between the concertino (smaller group) and the ripieno (large group). The performances of the Baroque orchestra centered around the aristocratic saloons, the church and homes. Orchestral and concert music performances here were for either a royal wedding, a religious service, celebrations or for the coronation of Kings.

\subsection{The Classical Orchestra}

The Classical Masters established the orchestra as it is known today but they based the ensemble on the blending of four instrumental classes namely, the strings, wood-winds, brass and the percussions. The backbone of the orchestra is the string family made up of violins, violas, violon cellos and Double basses. The establishment of the classical orchestra brought into play the use of dynamic signs such as forte, crescendo, diminuendo, piano etc which are still being used in modern orchestral scores. The centre stage in the classical instrumental music was taken up by the symphony which adopted the format of the Sonata-Allegro form for the first and last movements. It grew rapidly in dimension and significance until the last works of Haydn and Mozart. The greatest step forward however took place when Haydn was appointed Kapellmeister to Prince Esterhazy at Eisenstadt. Here he was gradually able to increase the size of the orchestra, hold daily rehearsals and discovered the best way of writing for an orchestra.

This is in confirmation with the words of Rimsky-Korsakov in Machlis (1984) when he said;

Orchestration is part of the very soul of the work. A work is thought out in terms of the orchestra, certain tone-colors being inseparable from it in the mind of its creator and native to it from the hour of birth. (p. 40)

The classical orchestra ranged from 17 permanent musicians in the orchestra of Princes Charles of Prussia in 1754 to 41 in the ensemble of Frederick the Great in 1782 . The $18^{\text {th }}$ century artists created music for a public, high above him in social rank and his works were usually enjoyed by the aristocratic patrons. To this Machlis (1984) had this to say;

The artist under patronage was a master craftsman, an artisan working on direct commission from his patron. He produced works for immediate use, sustained by daily contact with the public.

Research in Social Sciences Vol. 1, No. 2, pp. 37-43 2018

DOI: 10.53935/2641-5305.v1i2.6

Email: sundaynnamani2010@yahoo.com Funding: This study received no specific financial support. Article History:

Received: 16 August 2018

Revised: 24 September 2018

Accepted: 29 October 2018

Published: 27 November 2018

(O) 2018 by the authors; licensee Academic

Publishing Group
Puthe

40
Thus, one of the finest $18^{\text {th }}$ century orchestras was found in the court of Duke Carl in Mannheim whose Kapellmeister was Johann Stamitz.

\subsection{The Romantic Orchestra}

Great changes in the moral political and social climate of an era are usually expressed in the art of the era. Precisely, this was the achievement of the Romantic Movement in music because it gave the composers the means of expressing what the age demanded from them. The industrial revolution brought about tremendous 
growth and improvement in the $19^{\text {th }}$ century orchestra. Some of these improvements include the development of the Boehm system for the wood winds and the valve or pistons for the brass.

With these developments therefore, the performance of the Romantic orchestra then shifted from the palace and church to the public concert halls and its audience became the middle class and the wider society. This gave the composers a means of expression more varies and colorful opportunities than ever before. As a result, by the end of the $19^{\text {th }}$ century, the standard size of most orchestras throughout the Western world was between 80-100 instrumentalists.

\subsection{The $20^{\text {th }}$ Century Orchestration}

The $19^{\text {th }}$ century composer was an heir to the experiences of the $19^{\text {th }}$ century orchestral traditions. The two major influences of this century came from the works of two masters of the art of orchestration namely, Rimsky - Korsakov and Richard Strauss. The repertoire of the $20^{\text {th }}$ century symphony orchestral music was truly rich and as a result every country produces composers who were committed to the growth of orchestral repertoire. This was the birth of nationalism in music. Today hundreds of instruments are used including a variety of keyboard instruments and percussions. The audience had also increased tremendously including people from all works of life.

\section{The Conducting of Choral/Vocal Music}

Choral music encompasses a broad variety of genres for solo voice and voices in combination with or without instrumental accompaniment. It also includes monophonic, polyphonic and a complex of other forms such as opera, oratorio, cantata, mass etc. During the $20^{\text {th }}$ century, especially after the world wars I \&II, vocal singing had assumed a position of great importance and popularity in the society. Schools, choirs and choruses, church choirs, community choirs and choruses sponsored by industrial and commercial firms, have increased in number, size and quality. Hence the need for a better and well articulated process of managing, leading and conducting these ensembles are highlighted. The basic function of a choral conductor is to interpret the music to the singers from his understanding. By the use of different means, he endeavours to instill life and vitality into the music - the end result of which can be a truly thrilling and genuinely aesthetic experience for both the performers and the listening audience. He must be more than a time beater bringing to bear his musical knowledge and interpretative wishes conveyed through his conducting technique. Nevertheless each conductor is likely to have his own methods, but the fundamental patterns are basically the same. It is very important to acknowledge the essence of the fundamental conducting patterns, but they are really subservient to the bodily and facial expressions that reflect the mood of the music. These expressing are very important in vocal singing. Since vocal ensembles are diverse, they have their own internal social structure which mirrors vividly that of the society it is meant to serve. As a result Norton (1994: 562) recommended that the conductor of such diverse ensemble should be able to conform "in the degree of authoritarism type of leadership, amount of freedom available to the individual players and so on". He concluded by saying that the audience listening to such an ensemble tends to be divided in their opinions.

\section{Conducting Of Instrumental and Choral Ensembles in Nigeria}

The history of the performance of Western type of music in Nigeria dates back to the period between 1844 and 1890. This period witnessed a proliferation of various musical activities in churches, schools and concert halls. To be precise, the first performance of Western music was staged in Lagos in 1860 and the audience consisted of merchants, churchmen, civil servants, students and artisans (Omojola; 1995).

There is orchestral music in the Apostolic Faith, Deeper Life Bible Church, Four Square Gospel Church, Mountain of Fire and Miracles, etc and choral music in Nigerian churches such as Methodist Church, Anglican Church, Christ Apostolic Church, Assemblies of God Church, Apostolic Faith Church, etc.

It is important to mention here that the development of orchestral and vocal music with its conducting procedures in Nigeria had largely been around the Musical Society of Nigeria (MUSON) Centre; some churches plus a few private groups.

\subsection{The Muson Centre}

The Muson centre established in 1983 was set up primarily to promote and encourage a better appreciation of music of the "classics". On a regular basis, it organizes between 5-6 concerts annually usually 
attended by a crowd of about one-two thousand spectators. In pursuit of this mission, the Muson Symphony Orchestra (MSO) engaged the services of Dr Paul Konye, an Assistant Professor of Music based in the United States to mark its inaugural performance at its outing in 2005. According to Akinsanya (2005), it was to "bring to fruition, the realization of a much anticipated and long-awaited objective of MUSON, to establish a top notch orchestra in Lagos". He was charged with the primary purpose of founding and grooming a reputable and credible orchestra for Muson.

Muson Symphony Orchestra is being groomed to be a disciplined, versatile and first rate orchestra. The hope is to present a minimum of six concerts every year. Through creative and exciting programming by its director, the orchestra hopes to cater to a wide variety of musical tastes and style. It hopes to present concerts devoted to families, children, the conservative concert patron and the casual listener. (p. 55).

The composition of the orchestra was as follows:

$\begin{array}{ll}\text { Violin 1 } & \\ \text { Violin II } & \\ \text { Viola } & 4 \\ \text { Flutes } & 2 \\ \text { Oboes } & 1 \\ \text { Clarinets } & 2 \\ \text { Bassoon } & 1 \\ \text { French horn } & 3 \\ \text { Trumpets } & 2 \\ \text { Trombones } & 2 \\ \text { Timpani } & 1 \\ \text { Cello } & 4 \\ \text { Double Bass } & 1 \\ \text { Accompanist } & 1 \\ \text { Concertmaster } & 1\end{array}$

They performed among other classical pieces Symphony No 1 by L. V. Beethoven (Adagio moltoallegro); Piano concerto No 23 in A by W. A. Mozart (Allegro, Adagio, Allegro, Assai), Lullaby (String Orchestra) by Fela Sowande; I could have Danced, All Night (My Fair Lady) Frederick Loewe, String Orchestra, etc. (Konye, 2007) In 2016, they staged a concert on Dec $4^{\text {th }}$. We also have other private groups such as the Ayonmike Group, the Laz Ekwueme group etc.

\subsection{Church Orchestras}

The churches whose orchestras perform in Nigeria include: The Apostolic Faith Church, Four Square Gospel, Mountain of Fire and Ministries and others. Prominent amongst these churches is the Apostolic Faith Orchestra.

\subsection{The Apostolic Faith Church Orchestra}

The Apostolic Faith Church is believed to be one of the first few churches in Nigeria to develop a symphony orchestra with the largest single choir and symphony orchestra in Africa. It started in 1945 with a very humble beginning of two musical instruments. This symphony orchestra was founded and directed by Rev. Timothy G. Oshokoya - conductor and instrumentalist. (National Music Director, p.c).

According to Prof Fakorede, the pioneer members contributes immensely to the growth and development of this orchestra through teaching, conducting tests/evaluation, provision of music scores and other materials. (Fakorede p.c.) Presently, the orchestration has a numerical strength of about 1,500 instrumentalists and voices comprising of only three families of strings, woodwinds and brass. Commenting on the beginning of the orchestra, Soyinka (1994) had this to say; "Our orchestra started with a humble beginning. It was an orchestra of two pieces of musical instruments whose players were the two leading ministers". 
The Apostolic Faith orchestra had always staged public concerts at the National headquarters three times in a year that is during August Camp meetings, Easter and Christmas periods and at other times at the seven regional headquarters of the church across Nigeria.

A recent development is the establishment of Youth and Children's Orchestra. In August 2016, the Senior, Youth and Children's orchestras staged music concerts on $13^{\text {th }}, 20^{\text {th }}$ and $27^{\text {th }}$ August respectively and the researcher was present. The audience participation in all these had always been tremendous. The music directors of this group had always publicized their concert programmes in newspapers, radios, posters and televisions. The print and electronic media in addition to publicizing it had always been represented at these venues. Some of the recorded and published articles read thus:

Africa's single largest orchestra of 600 (six hundred) piece from the National choir of the Apostolic Faith will on Monday 8 August, 1994 stage an international classical music concert at the African headquarters of the church. (Adekunle, 1994).

In the same vein Olusegun (1994) asserted that;

A 600 (six hundred) piece orchestra from the national choir/orchestra of the Apostolic Faith began an international classical music concert at the Apostolic Faith headquarters Anthony, yesterday. The evening of music is one of the highlights of the $50^{\text {th }}$ anniversary programme... 15,000 (fifteen thousand) persons were in attendance.

Very important personalities and dignitaries such as former heads of state, Directors, Ministers, Obas, Chiefs, etc had always attended the church's concerts (Nnamani, 1996)

\section{The Nigerian Audience}

The Nigerian audience especially the literate ones had always patronized such performances where the conductors exhibit their skills of musical direction. But suffice it to say that the evaluation of conductors occurs at every performance by the players, the management, by critics and by the audience. From the foregoing, it will be observed that the awareness for the attendance of instrumental and vocal music performances had not been sufficiently created among the middle and lower class of the Nigerian populace as it is with popular music. It is therefore recommended that members of the public should attend such performances in order to release tensions accumulated from the hustle and bustle of the present day society.

\section{References}

Adekunle, F (1994). Top life Newspapers, August $11^{\text {th }}$ pp.2.

Akinsanya, O.A (2005). Message from the Festival Planning Committee Chair. MUSON Festival 2005 pp.5.

Fakorede, D (1996). Deputy National Director Apostolic Choir and Orchestra In Sunday N. Nnamani. The Place and Role of the Apostolic Faith Choir and Orchestra in the Music Education of the Lagos Africa Headquarters Community. M. A. Thesis, University of Nigeria, Nsukka.

Konye, P. (2007). African Art Music: Political, Social and Culture Factors behind its Developmental Practice in Nigeria. Edwin Mellen Press. ISBN 9780773452534.

Machlis, J. (1984). The Enjoyment of Music. W.W. Norton and Company Press.

National Music Director, Apostolic Faith Choir and Orchestra, Lagos. personal communication In Sunday N. Nnamani. The Place and Role of the Apostolic Faith Choir and Orchestra in the Music Education of the Lagos Africa Headquarters Community. M. A. Thesis, University of Nigeria, Nsukka.

Nnamani, S. N (1996). The Place and Role of the Apostolic Faith Choir and Orchestra in the Music Education of the Lagos Africa Headquarters Community. M. A. Thesis, University of Nigeria, Nsukka.

Norton, P. (1994). The New Encyclopedia Britannica. London: Norton Publications, 3.

Olusegun, S. (1994). Punch Newspapers, August $9^{\text {th }}$ p. 3

Omojola, O. (1995). Nigerian Art Music. Ibadan IFRA

Pei, M. (1983). The Lexican Webster Dictionary. USA : Debir Pub. Coy.

Robertson Stevens, D. (1981). "The Pelican History of Music". Vol II. Penguin Books, Britain.

Soyinka, J. (1994). The Man with a Vision. The Biography of Late Rev. T.G. Oshokoya. Apostolic Faith Publishing House, Anthony Village, Lagos.

Westrup, J. et al (1976). Collins Encyclopedia of Music. Glasgow 